\title{
The effect of cigarette smoking use and cessation on serum insulin-like growth factors
}

\author{
AG Renehan",', WS Atkin', ST O'Dwyer' and SM Shalet ${ }^{3}$ \\ 'Department of Surgery, Christie Hospital NHS Trust, Wilmslow Road, Manchester M20 4BX, UK; ${ }^{2}$ Cancer Research UK Colorectal Unit, St Mark's \\ Hospital, London, UK; ${ }^{3}$ Department of Endocrinology, Christie Hospital NHS Trust, Manchester, UK
}

The patterns of risk association between circulating levels of insulin-like growth factor (IGF)-I, and its main binding protein, IGFBP-3, differ between smoking and nonsmoking-related cancers. To investigate this observation further, we measured serum IGF-I, IGF-II and IGF-binding protein-3 concentrations in 232 men and 210 women (aged 55-64 years), and related peptide levels to smoking characteristics. Current smoking was associated with significant reductions in mean IGFBP-3 levels in men assessed by the number of cigarettes smoked daily $\left(P_{\text {trend }}=0.007\right)$ and pack-years smoked $\left(P_{\text {trend }}=0.03\right)$. Mean IGF-I levels decreased with increasing cigarette use in men $\left(P_{\text {trend }}=0.1 \mathrm{I}\right)$. There were no patterns of association between smoking and IGF peptides in women. For male former vs never smokers, there were no differences in mean IGF-I and IGFBP-3 concentrations, suggesting that smoking cessation is associated with normalisation of peptide concentrations.

British Journal of Cancer (2004) 91, I525-1531. doi:I0.1038/sj.bjc.6602I 50 www.bjcancer.com

Published online 31 August 2004

(C) 2004 Cancer Research UK

Keywords: insulin-like growth factors; IGF-binding proteins; cancer risk; cigarette smoking

Insulin-like growth factor-one (IGF-I) is a multifunctional regulatory peptide important in tumour cell growth and survival (Jones and Clemmons, 1995). In the circulation, IGF-I is predominantly bound $(>90 \%)$ to the major insulin-like growth factor-binding protein, IGFBP-3 (Clemmons, 1997). Unlike most other growth factors, the IGFs have classical endocrine as well as local paracrine influences on cell behaviour (Rajaram et al, 1997). Concentrations of circulating total IGF-I and IGFBP-3 are influenced by growth hormone, age (levels decline with age after puberty), gender and nutritional status (Thissen et al, 1994; Juul, 2003). Nevertheless, measurement of circulating IGF peptides levels can be used as a marker of the general body stores (Holly and Hughes, 1994).

Across the general population, there are wide interindividual variations in IGF-I and IGFBP-3 concentrations, which may impact upon cancer risk (Pollak, 2000; Yu and Rohan, 2000). In a recent systematic review and meta-regression analysis of 21 studies, we determined the associations between circulating IGF-I and IGFBP3 levels and cancer risk (Renehan et al, 2004), and demonstrated that the patterns of association differed between smoking and nonsmoking-related cancer. Specifically, total IGF-I concentrations are positively associated with the risk of prostate, colorectal and pre-menopausal breast cancers, but not lung cancer, while total IGFBP-3 concentrations are positively associated with the risk of pre-menopausal breast cancer, and, after excluding a recruitmentbias study, inversely associated with lung cancer risk. A further population-based study reported that IGFBP-3 concentrations are inversely associated with increased risk of lung cancer mortality, but noted no association with serum IGF-I levels (Wakai et al, 2002). In light of these epidemiological observations, we hypothe-

*Correspondence: Dr AG Renehan; E-mail: arenehan@picr.man.ac.uk Revised 7 July 2004; accepted 16 July 2004; published online 31 August 2004 sised that cigarette smoking may influence IGF physiology. Thus, the aim of this study was to determine the relationships of serum IGF-I, IGF-II and IGFBP-3 with characteristics of smoking exposure.

\section{MATERIALS AND METHODS}

\section{Study design}

Using a cross-sectional design, we studied 232 men and 210 women attending one centre (1998-99) within the Flexi-Scope colorectal cancer screening trial (Flexi-Scope-Trial-Collaborators, 2002). Participants were healthy ambulatory individuals aged 5564 years, invited by open invitation from general medical practitioner registries. With Ethics Committee approval and after obtaining informed consent, a trained researcher interviewed participants. Smoking exposure was evaluated using a modification of the European Prospective Investigation into Cancer (EPIC) study questionnaire (Sargeant et al, 2001), and individuals categorised as never, former and current smokers. Computed exposure variables included pack-years smoked, that is, number of packs (one pack $=20$ cigarettes) smoked per day multiplied by the number of years smoked. Participants were questioned about medical history and defined as having major illness in accordance with EPIC study criteria (Sargeant et al, 2001) (see footnote to Table 1). Hormonal replacement therapy (HRT) use in women was also recorded. Details of alcohol consumption, physical activity and diet were not available. For each participant, height and weight were measured, and body mass index (BMI) accordingly calculated as weight $/$ height $^{2}\left(\mathrm{~kg} \mathrm{~m}^{-2}\right)$.

\section{Blood collection}

Blood was obtained in clotted tubes and immediately transported to the laboratory. Serum was isolated by centrifugation at 
Table I Characteristics of 232 men and 210 women, aged 55-64 years

\begin{tabular}{|c|c|c|c|}
\hline & $\begin{array}{l}\text { Never } \\
\text { smokers }\end{array}$ & $\begin{array}{l}\text { Former } \\
\text { smokers }\end{array}$ & $\begin{array}{l}\text { Current } \\
\text { smokers }\end{array}$ \\
\hline \multicolumn{4}{|l|}{ Men } \\
\hline Number of participants & 91 & 96 & 45 \\
\hline \multicolumn{4}{|l|}{ Mean (s.d.) } \\
\hline Age (years) & $60.8(2.8)$ & $60.8(2.8)$ & $60.5(2.6)$ \\
\hline Height $(\mathrm{cm})$ & $175(7.1)$ & |76.| (6.5) & $175(6.8)$ \\
\hline Weight $(\mathrm{kg})$ & $80.4(13.6)$ & $82.6(10.6)$ & $79.6(12.4)$ \\
\hline $\mathrm{BMI}\left(\mathrm{kg} \mathrm{m}^{-2}\right)^{\mathrm{a}}$ & $26.3(4.5)$ & $26.6(3.2)$ & $26.0(3.4)$ \\
\hline Age started smoking (years) & - & $17.2(3.3)$ & $20.1(7.5)$ \\
\hline Duration smoking (years) & - & $22.5(9.7)$ & $40.4(8.1)$ \\
\hline Cigarettes per day & - & $20.4(14.4)$ & $17.0(10.0)$ \\
\hline $\begin{array}{l}\text { Pack-years of cigarette } \\
\text { smoking }\end{array}$ & - & $23.7(20.2)$ & $33.9(20.5)$ \\
\hline $\begin{array}{l}\text { Age when quit smoking } \\
\text { (years) }\end{array}$ & - & $39.6(9.2)$ & - \\
\hline \multicolumn{4}{|l|}{ Numbers (\%) } \\
\hline Caucasian & $86(95)$ & $87(9 \mid)$ & $4 \mid(9 \mid)$ \\
\hline Current aspirin use & $15(17)$ & $18(19)$ & $9(20)$ \\
\hline Major illness ${ }^{c}$ & $23(25)$ & $42(44)$ & $12(27)$ \\
\hline Diabetes mellitus & $3(3)$ & $9(9)$ & $1(2)$ \\
\hline \multicolumn{4}{|l|}{ Women } \\
\hline Number of participants & 110 & 60 & 40 \\
\hline \multicolumn{4}{|l|}{ Mean (s.d.) } \\
\hline Age (years) & $59.7(2.7)$ & $60.5(2.7)$ & $59.6(2.6)$ \\
\hline Height $(\mathrm{cm})$ & $162(6)$ & $162(7)$ & $163(7.1)$ \\
\hline Weight $(\mathrm{kg})$ & $69.5(10.8)$ & $70.8(13.9)$ & $68.2(10.1)$ \\
\hline BMI $\left(\mathrm{kg} \mathrm{m}^{-2}\right)^{\mathrm{a}}$ & $26.6(4.3)$ & $26.9(5.3)$ & $25.8(3.9)$ \\
\hline Age started smoking (years) & - & $19.5(3.9)$ & $19.9(8.3)$ \\
\hline Duration smoking (years) & - & $21.0(10.4)$ & $39.5(8.5)$ \\
\hline Cigarettes per day & - & $12.4(6.7)$ & $13.9(7.9)$ \\
\hline $\begin{array}{l}\text { Pack-years of cigarette } \\
\text { smoking }\end{array}$ & - & $13.9(12.5)$ & $28.3(18.2)$ \\
\hline $\begin{array}{l}\text { Age when quit smoking } \\
\text { (years) }\end{array}$ & - & $40.5(10.3)$ & - \\
\hline \multicolumn{4}{|l|}{ Numbers (\%) } \\
\hline Caucasian & $106(96)$ & $58(97)$ & $40(100)$ \\
\hline Current aspirin use & $13(12)$ & $5(8)$ & $5(13)$ \\
\hline Major illness ${ }^{c}$ & $29(26)$ & $14(23)$ & $9(23)$ \\
\hline Diabetes mellitus & $3(3)$ & $2(2)$ & I (3) \\
\hline Current HRT user ${ }^{d}$ & $42(38)$ & $23(38)$ & $18(45)$ \\
\hline Ever HRT user & $50(46)$ & $29(48)$ & $20(50)$ \\
\hline
\end{tabular}

s.d. $=$ standard deviation. ${ }^{\mathrm{a}} \mathrm{BMI}=$ body mass index. ${ }^{\mathrm{b}}$ Pack-years presented as median (inter-quartile range). 'Major illness included: high blood pressure (hypertension) requiring treatment with drugs, high blood cholesterol (hyperlipidemia), angina, heart attack (myocardial infarction), stroke, other vascular disease (peripheral vascular disease), diabetes mellitus (excluding gestational diabetes) and cancer. ${ }^{\mathrm{d}} \mathrm{HRT}=$ horhormonal replacement therapy; Current use defined as within the past 6 months.

3000 r.p.m. for $10 \mathrm{~min}$ at room temperature and stored at $-80^{\circ} \mathrm{C}$ before analyte determination. Within the study, several quality control tests were performed, which demonstrated that: (i) repeated analyte sampling over short periods in healthy individuals showed minimal variation; (ii) time from venepuncture to processing had little impact and (iii) there was long-term stability at $-80^{\circ} \mathrm{C}$ storage (Renehan, 2004).

\section{Measurements of IGF-I, IGF-II and IGFBP-3}

Serum IGF-I concentrations were measured, following acidalcohol extraction, by an established in-house radioimmunoassay (Renehan et al, 2000b, 2001). Serum IGF-II and IGFBP-3 levels were determined using a commercially available immuno-radiometric assays kit (Diagnostic Systems Laboratories, Inc. Webster, TX, USA). All determinants were measured in duplicate blind to cigarette and gender status. The IGF-I/IGFBP-3 molar ratio was calculated using the conversion: $1 \mathrm{ng} \mathrm{ml}^{-1}$ is $0.130 \mathrm{nmoll}^{-1}$ for IGF-I and $0.036 \mathrm{nmoll}^{-1}$ for IGFBP-3. The coefficients of variation
(CVs) for intra- and inter-assay testing were less than 5 and $10 \%$, respectively (Renehan et al, 2003).

\section{External validity}

Studies from the Flexi-Scope Trial have shown that the distribution across social classes is broadly representative of the general population (McCaffery et al, 2002). In addition, baseline characteristics of this study cohort by smoking status were similar to those reported for age-matched UK populations (Appendices A1 and $\mathrm{B} 1$ ).

\section{Statistical analysis}

Data were analysed separately for men and women as we previously reported significant differences in mean IGF-I, IGF-II and IGFBP-3 concentrations by gender (Renehan et al, 2000b). All analytes were parametrically distributed (Kolmogorov-Smirnov test), and thus the principal results were expressed as means and standard deviations (s.d.). For descriptive analysis, Student's $t$ tests, one-way ANOVA and chi-squared $\left(\chi^{2}\right)$ tests were used.

With smoking characteristics as the principal factor of interest, we evaluated for trends across serum IGF concentrations using linear regression models. As factors of interest may have trends in opposite directions in current $v$ s former smokers (e.g. BMI) (Chao et al, 2000; DoH, 2000; Sargeant et al, 2001), we analysed the data separately for never (referent) vs current smokers, and never $v s$ former smokers. As the distributions for quantifying smoking exposure were not continuous - for example, participants tended to report the number of cigarettes smoked per day in multiples of five - we determined the ranks for these variables based on arbitrary cutoff points. Thus, for instance, the average number of cigarettes per day was ranked as 1,2 and 3, for $<5,15-24$ and $\geqslant 25$ cigarettes smoked per day, respectively. Never smokers were then denoted as zero and models constructed. Model A (univariate) was unadjusted with dependent variables IGF-I, IGFII, IGFBP-3 and the IGF-I/IGFBP-3 molar ratio. Model B was adjusted for age and ethnicity as IGF levels decline with age after puberty (Juul, 2003) and vary between ethnic groups (Platz et al, 1999). We included both BMI and height in this model to capture information on both body composition and body size. For women, we included current (within past 6 months) use of HRT as its use is associated with reductions in mean IGF-I and IGFBP-3 concentrations (Leung et al, 2004). To accommodate the opposing effects of IGF-I and IGFBP-3 $(r=0.59, P<0.001)$, and IGF-II and IGFBP-3 $(r=0.61, P<0.001)$, model $\mathrm{C}$ included adjustments for IGFBP-3 where IGF-I and IGF-II were dependent variables, and for IGF-I where IGFBP-3 was the dependent variable. Results were reported as $\beta$ coefficients, and their standard errors (s.e.) and the total model $r^{2}$ were calculated to provide a sense of the model variability and strength of fit (STATA version 7.0: StataCorp, College Station, TX, USA).

\section{RESULTS}

The study baseline characteristics are shown in Table 1. Of the 442 participants, $19 \%$ of men and $19 \%$ of women were current smokers; $41 \%$ of men and $29 \%$ of women were former smokers at the time of blood sampling. As reported in other studies (Chao et al, 2000; DoH, 2000; Sargeant et al, 2001), current smoking was associated with lower BMI values in both genders, while former smoking was associated with higher BMI values, compared to that for never smoking. Men tended to start smoking at an earlier age, smoke more cigarettes per day and had greater pack-years of smoking, compared with women. In all, 40\% (83 out of 210) of women were current HRT users. 
Table 2 Serum concentrations of IGF-I, IGF-II, IGFBP-3 and the molar IGF-I/ IGFBP-3 ratio by smoking status in men and women

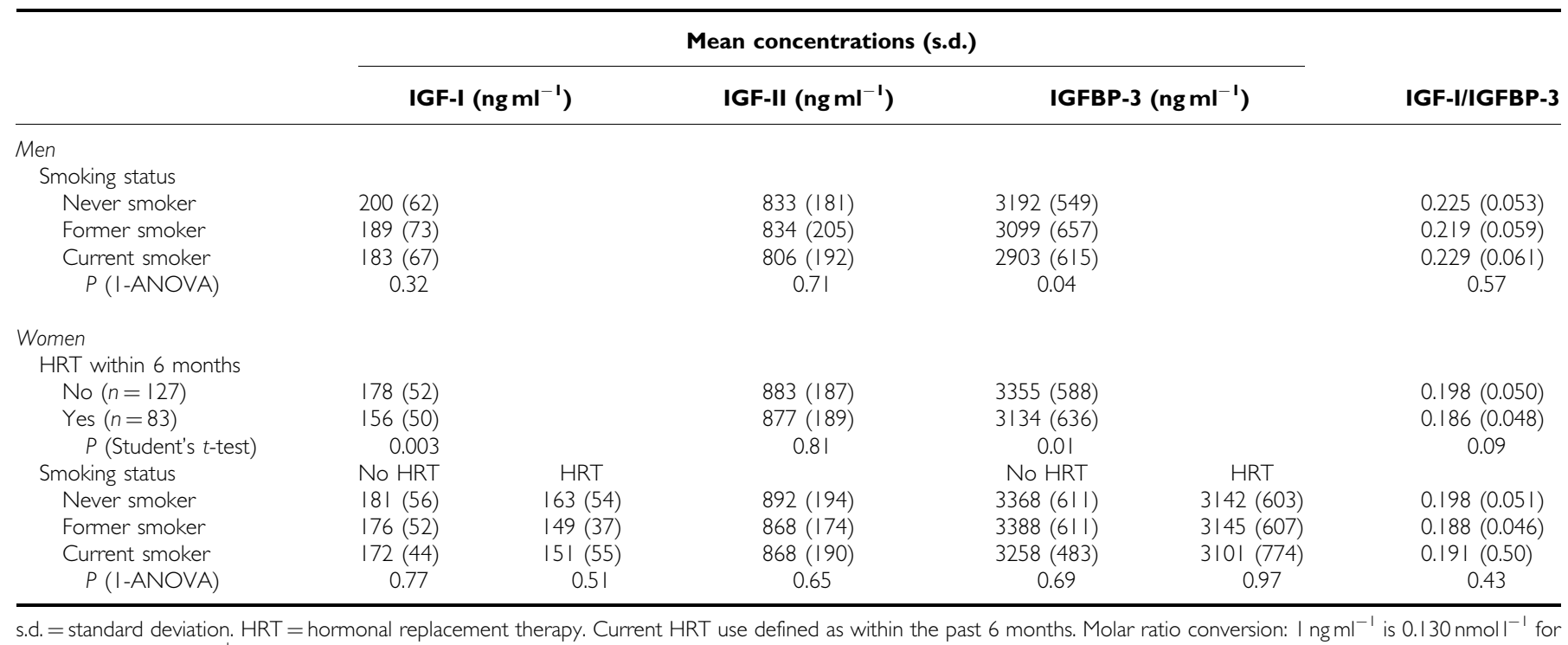

IGF-I and $0.036 \mathrm{nmol}^{-1}$ for IGFBP-3.

The mean concentrations for serum IGF-I, IGF-II, IGFBP-3 and calculated IGF-I/IGFBP-3 molar ratio according to gender and smoking status are shown in Table 2. With never smokers as referents, mean levels for IGF-I were higher (mean difference $=26.1,95 \%$ confidence interval, 9.7-42.4 $\mathrm{ng} \mathrm{ml}^{-1}$ ), IGF-II were lower $\left(-59.3,-112.0\right.$ to $\left.-6.7 \mathrm{ng} \mathrm{ml}^{-1}\right)$, IGFBP-3 were lower $\left(-89.6,-253.3\right.$ to $\left.74.1 \mathrm{ng} \mathrm{ml}^{-1}\right)$, and IGF-I/IGFBP-3 ratio were higher $(0.028,0.007-0.013)$ in men compared with women. Among men, smoking was associated with nonsignificant reductions in mean serum IGF-I levels, but significant reductions in mean IGFBP-3 levels (1-ANOVA, $P=0.04)$. As expected, the current use of HRT in women was associated with significant reductions in mean serum IGF-I (Student's $t$-test, $P=0.003$ ) and IGFBP-3 $(P=0.01)$ concentrations. After taking account of HRT status, there was no significant association between mean IGF-I or IGFBP-3 concentrations and smoking habit in women. There were no distinct patterns of association between smoking and serum IGF-II.

We evaluated for trends in IGF peptide concentrations and smoking exposure (Table 3). Among male current smokers, and taking never smokers as zero cigarettes, there were significant reductions in mean IGFBP-3 concentrations assessed as the number of cigarettes smoked per day (unadjusted: $\beta=-144$, s.e. $\left.=51, P_{\text {trend }}=0.005, r^{2}=0.057\right)$ and as pack-years smoked $\left(\beta=-108\right.$, s.e. $\left.=46, P_{\text {trend }}=0.02, r^{2}=0.040\right)$. These significant trends remained after adjustments for age, ethnicity, height, BMI and IGF-I (fully adjusted: $\beta=-113$, s.e. $=41, \quad P_{\text {trend }}=0.007$, $r^{2}=0.421$ and $\beta=-82$, s.e. $=37, P_{\text {trend }}=0.03, r^{2}=0.410$, respectively). Among female current smokers, there were nonsignificant reductions in mean IGFBP-3 levels with increasing smoking exposure (fully adjusted: $\beta=-48, \quad$ s.e. $=42, \quad P_{\text {trend }}=0.25$, $r^{2}=0.356$ and $\beta=-51$, s.e. $=43, P_{\text {trend }}=0.24, r^{2}=0.356$ for cigarettes per day and pack-years, respectively). For men, there was a nonsignificant trend towards reduced mean IGF-I levels with increasing smoking exposure $\left(P_{\text {trend }}=0.11\right)$, but no association after adjustment for IGFBP-3. There were no trends for IGF-I in women, and IGF-II or the IGF-I/IGFBP-3 ratio in both genders.

Data from the UK Doctor's study (Peto et al, 2000) have shown that the risk of smoking-related cancers returns towards general population risk levels with increasing duration since smoking cessation. To test the relevance of this observation to circulating
IGFs, we evaluated the trends in mean analyte levels by categories of years since quit smoking, and age when quit smoking (Table 4). In general, mean values for serum IGF-I, IGF-II, IGFBP-3 and IGFI/IGFBP-3 ratios demonstrated no difference among former smokers compared to current smokers. Mean IGFBP-3 levels in men who recently stopped smoking were lower than those in never smokers, but this did not reach statistical significance.

\section{DISCUSSION}

Cigarette smoking was associated with significant exposure-related reductions (up to 13\%) in mean serum IGFBP-3 levels in men (and to a lesser extent in women), an observation which may be relevant for smoking-related tumour development. Smoking tended to decrease mean IGF-I levels in men, but these changes may reflect parallel reductions in IGFBP-3 concentrations. Mean IGF-I and IGFBP-3 levels were similar for former smokers and never smokers, suggesting that these markers of cancer risk normalise following smoking cessation.

An advantage of this study was the narrow age-defined population-based cohort, as we and others have shown that circulating levels of IGF peptides change over a wide age range in a nonlinear fashion (Renehan et al, 2000a; Juul, 2003). Comparing never $v s$ current smokers, and never $v s$ former smokers, was another key study feature, as factors of interest may influence IGF physiology in opposite directions in different smoking groups. In addition, in previous studies, smoking exposure has often been treated as an ordinal scale variable (never, former smoker, current smoker) without taking account of quantities smoked and the time period of exposure. Having taken account of these factors, the current study demonstrated significant exposure-related trends in IGFBP-3 levels.

The relatively small numbers in the smoking categories and the cross-sectional design with once-only analyte measurements were potential disadvantages of the study. Further limitations were the lack of data for alcohol consumption, dietary factors and physical activity. For alcohol consumption, a factor known to be associated with cigarette smoking, studies have shown inconsistent relationships with serum IGF-I concentrations - increase (Goodman Gruen and Barrett Connor, 1997; Kaklamani et al, 1999), decrease 
Table 3 Serum concentrations of IGF-I, IGF-II, IGFBP-3 and the molar IGF-I/ IGFBP-3 ratio by smoking characteristics in men and women

Mean concentrations (s.d.)

$n \quad I G F-I\left(\mathrm{ng} \mathrm{ml}^{-1}\right) \quad$ IGF-II $\left(\mathrm{ng} \mathrm{ml}^{-1}\right) \quad$ IGFBP-3 $\left(\mathrm{ng} \mathrm{ml}^{-1}\right) \quad$ IGF-I/IGFBP-3

\begin{tabular}{|c|c|c|c|c|c|}
\hline \multicolumn{6}{|l|}{ Men } \\
\hline \multicolumn{6}{|l|}{ Number of cigarettes daily } \\
\hline I-14 cigarettes & 18 & $180(68)$ & 799 (209) & $2959(562)$ & $0.220(0.065)$ \\
\hline $15-24$ cigarettes & 17 & $190(54)$ & $799(165)$ & $2921(714)$ & $0.237(0.053)$ \\
\hline Model A, $P$ for trend & & 0.20 & 0.61 & 0.005 & 0.51 \\
\hline Model B, $P$ for trend & & 0.11 & 0.43 & 0.002 & 0.62 \\
\hline Model C, $P$ for trend & & 0.76 & 0.14 & 0.007 & - \\
\hline $21-39$ & 13 & 184 (67) & $690(194)$ & $2794(596)$ & $0.237(0.063)$ \\
\hline$\geqslant 40$ & 17 & $185(6 \mid)$ & $867(172)$ & $2963(649)$ & $0.229(0.061)$ \\
\hline Model A, $P$ for trend & & 0.22 & 0.65 & 0.02 & 0.66 \\
\hline Model B, $P$ for trend & & 0.15 & 0.48 & 0.009 & 0.70 \\
\hline Model C, $P$ for trend & & 0.87 & 0.24 & 0.03 & - \\
\hline$\geqslant 20$ cigarettes & 13 & $167(56)$ & $850(237)$ & $3020(811)$ & $0.209(0.054)$ \\
\hline Model A, P for trend & & 0.42 & 0.43 & 0.21 & 0.95 \\
\hline Model B, $P$ for trend & & 0.49 & 0.46 & 0.18 & 0.79 \\
\hline Model C, $P$ for trend & & 0.94 & 0.86 & 0.25 & - \\
\hline \multicolumn{6}{|l|}{ Current smokers, pack-years } \\
\hline Never (zero) & 110 & $174(56)$ & $892(194)$ & $3282(6 \mid 5)$ & $0.192(0.050)$ \\
\hline $1-18$ & 13 & $163(46)$ & $893(137)$ & $3345(473)$ & $0.175(0.043)$ \\
\hline $19-38$ & 14 & $159(5 \mid)$ & $857(194)$ & $3196(558)$ & $0.179(0.048)$ \\
\hline$\geqslant 39$ & 13 & $167(56)$ & $850(237)$ & $3020(811)$ & $0.203(0.052)$ \\
\hline Model A, P for trend & & 0.35 & 0.38 & 0.19 & 0.95 \\
\hline Model $B, P$ for trend & & 0.47 & 0.41 & 0.17 & 0.81 \\
\hline Model C, $P$ for trend & & 0.94 & 0.92 & 0.24 & - \\
\hline
\end{tabular}

s.d. = standard deviation. Pack-years were divided into tertiles based on the distribution of all current smokers for men and women. Multiple linear regression model A: unadjusted. Model B: adjusted for age, ethnicity, height, body mass index and current HRT status in women. Model C: adjusted for age, ethnicity, height, body mass index, current HRT status in women and IGFBP-3 for IGF-I and IGF-II as dependent variables, and IGF-I for IGFBP-3 as dependent variable.

(Teramukai et al, 2002) or no change (Holmes et al, 2002a) - but mainly positive correlations with IGFBP-3 (Holmes et al, 2002a; Teramukai et al, 2002). Recent reports suggest that plant-based diets (Holmes et al, 2002b), high-protein diets (Allen et al, 2003) and milk consumption (Ma et al, 2001; Gunnell et al, 2003) may be important determinants of circulating IGF peptide levels. However, cross-sectional studies fail to demonstrate consistent associations between circulating IGF peptides and level of physical activity (Landin Wilhelmsen et al, 1994; Voskuil et al, 2001; Holmes et al, 2002a; Teramukai et al, 2002). These need to be considered in future studies.

One other study (Kaklamani et al, 1999) has specifically determined the relationships between serum IGF peptides and smoking, but was limited to 130 individuals (only 22 current smokers) across a wide age range, men and women analysed together, and the regression analyses of relationships with smoking exposure (as a continuous variable) were limited to current smokers only, without taking account of never smokers (i.e. zero). Additional studies have determined IGF-smoking relationships within wider analyses of associations with lifestyle and/or anthropometric factors. Despite these differences in design, there are emerging consistent observations: (i) across different populations - Japanese (Teramukai et al, 2002), Greek (Kaklamani et al, 1999), American (Chang et al, 2002), United Kingdom (present study) - there are reductions in mean IGFBP-3 levels with smoking in men, but not in women (Chang et al, 2002; Holmes et al, 2002a); (ii) associations between serum IGF-I and cigarette smoking are generally inverse in men (Landin Wilhelmsen et al, 1994; Teramukai et al, 2002), but weak (Holmes et al, 2002a) or absent (Landin Wilhelmsen et al, 1994) in women. However, in postmenopausal women, the expected reductions in mean serum IGF-I levels associated with HRT usage may be greater among current smokers (Chang et al, 2002). Unique to our study, we showed that the trend towards reduced mean IGF-I levels with increasing smoking was attenuated after adjustment for IGFBP-3, suggesting that these changes may be dependent on parallel reductions in IGFBP-3 concentrations.

What are the implications for cancer mechanisms? For lung cancer, the findings of the current study are consistent with our meta-analysis (Renehan et al, 2004) that reported no association with circulating IGF-I but a significant inverse association with IGFBP-3 (after excluding a heavy smokers-only study). An inverse role for IGFBP-3 in lung tumorigenesis is supported by the observation that constitutive expression of IGFBP-3 inhibits the growth of non-small-cell lung cancer (Lee et al, 2002). Yet, for premenopausal breast cancer, there is a positive association between circulating IGFBP-3 and cancer risk (Renehan et al, 2004). These apparent paradoxes are not unexpected as the cellular functions of 
Table 4 Serum concentrations of IGF-I, IGF-II, IGFBP-3 and the molar IGF-I/ IGFBP-3 ratio by past smoking characteristics (in ex-smokers) in men and women

\begin{tabular}{|c|c|c|c|c|c|}
\hline & $n$ & \multicolumn{4}{|c|}{ Mean concentrations (s.d.) } \\
\hline \multicolumn{6}{|l|}{ Years since quit smoking } \\
\hline Never (zero) & 91 & $200(62)$ & $833(|8|)$ & $3192(549)$ & $0.225(0.053)$ \\
\hline$\geqslant 20$ years & 56 & $183(55)$ & $813(196)$ & $3098(655)$ & $0.214(0.050)$ \\
\hline $10-19$ years & 26 & $207(93)$ & $843(174)$ & $3128(638)$ & $0.236(0.072)$ \\
\hline Never & 91 & $200(62)$ & $833(|8|)$ & $3192(549)$ & $0.225(0.053)$ \\
\hline Before aged 35 years & 36 & $188(59)$ & $794(213)$ & $3168(722)$ & $0.215(0.052)$ \\
\hline Aged $35-44$ years & 31 & $198(88)$ & $876(156)$ & $3150(567)$ & $0.226(0.072)$ \\
\hline Aged 45 years and after & 29 & $179(72)$ & $838(235)$ & $2958(665)$ & $0.217(0.055)$ \\
\hline$P$ for trend $d^{a}$ & & 0.67 & 0.02 & 0.39 & 0.85 \\
\hline Less than 10 years & 14 & $160(46)$ & $884(161)$ & $3201(553)$ & $0.187(0.044)$ \\
\hline$P$ for trend ${ }^{b}$ & & 0.24 & 0.49 & 0.62 & 0.21 \\
\hline \multicolumn{6}{|l|}{ Age when quit smoking } \\
\hline Never & 110 & $174(56)$ & $892(194)$ & $3282(6 \mid 5)$ & $0.198(0.051)$ \\
\hline Before age 35 years & 22 & $\mid 64(5 \mid)$ & $881(190)$ & $3334(700)$ & $0.185(0.048)$ \\
\hline Aged $35-44$ years & 18 & $166(55)$ & $827(183)$ & $3261(653)$ & $0.189(0.053)$ \\
\hline Aged 45 years and after & 20 & $167(42)$ & $891(148)$ & $3283(502)$ & $0.190(0.040)$ \\
\hline$P$ for trend ${ }^{b}$ & & 0.31 & 0.39 & 0.70 & 0.28 \\
\hline
\end{tabular}

s.d. = standard deviation. ${ }^{2}$ Models adjusted for age, ethnicity, height, body mass index and IGFBP-3 for IGF-I and IGF-II as dependent variables, and IGF-I for IGFBP-3 as dependent variable. 'Models adjusted for age, ethnicity, height, body mass index, current HRT status and IGFBP-3 for IGF-I and IGF-II as dependent variables, and IGF-I for IGFBP-3 as dependent variable.

IGFBP-3 are multi-directional and, depending on the cellular environment, may be inhibitory (through sequestration of IGF ligand), antiproliferative and proapoptotic (Firth and Baxter, 2002) or antiapoptotic (McCaig et al, 2002) via IGF-independent pathways. Whereas some authors (Pollak, 2000; Yu and Rohan, 2000) have hypothesised that the relative levels of IGF-I to IGFBP-3 may be important for cancer risk, the absolute quantities (reflecting total body stores) may be more pertinent, remembering that IGFBP-3 circulates in molar concentrations considerably (fivefold) greater than IGF-I.

The study findings suggest (albeit indirectly) that serum IGF-I and IGFBP-3 levels normalise after smoking cessation, an observation that is clearly relevant to cancer prevention. However, a clear understanding of the 'ups and downs' of IGF-I and IGFBP-3 is required. Thus, for example, cancer prevention trials (McTiernan, 2003) are currently being designed to modulate circulating IGF-I and IGFBP-3 as biomarkers of cancer risk, and paradoxical results may be predicted for nonsmokers $v s$ smokers - an increase in serum IGF-I levels after smoking cessation may simply reflect peptide normalisation rather than represent a prediction of increased cancer risk.

The reasons why smoking induces reductions in IGFBP-3 levels and why there are gender differences are unclear. However, the merit of this study is that it focuses attention on smoking as a modifiable influence of circulating IGF peptides, surrogate markers of common cancer risk.

\section{ACKNOWLEDGEMENTS}

We are indebted to Jenny Jones for her laboratory analyses (Diagnostic Systems Laboratories, SL, King's College, London). This study was in part financially supported by the Endocrine Endowment Funds, Christie Hospital NHS Trust and the Royal College of Surgeons of Edinburgh, Royal Bank of Scotland Fellowship award. The sponsors had no input into the interpretation and writing of this paper.

\section{REFERENCES}

Allen NE, Appleby PN, Kaaks R, Rinaldi S, Davey GK, Key TJ (2003) Lifestyle determinants of serum insulin-like growth-factor-I (IGF-I), Cpeptide and hormone binding protein levels in British women. Cancer Causes Control 14: 65-74

Chang S, Wu X, Yu H, Spitz MR (2002) Plasma concentrations of insulinlike growth factors among healthy adult men and postmenopausal women: associations with body composition, lifestyle, and reproductive factors. Cancer Epidemiol Biomarkers Prev 11: 758-766

Chao A, Thun MJ, Jacobs EJ, Henley SJ, Rodriguez C, Calle EE (2000) Cigarette smoking and colorectal cancer mortality in the cancer prevention study II. J Natl Cancer Inst 92: 1888-1896

Clemmons DR (1997) Insulin-like growth factor binding proteins and their role in controlling IGF actions. Cytokine Growth Factor Rev 8: $45-62$

Department of Health (2000) Health Survey of England, 1998 Cardiovascular Disease Table 3.13 and Table 3.22 
Firth SM, Baxter RC (2002) Cellular actions of the insulin-like growth factor binding proteins. Endocr Rev 23: $824-854$

Flexi-Scope-Trial-Collaborators (2002) Single flexible sigmoidoscopy screening to prevent colorectal cancer: baseline findings of a UK multicentre randomised trial. Lancet 359: 1291-1300

Goodman Gruen D, Barrett Connor E (1997) Epidemiology of insulin-like growth factor-I in elderly men and women. The Rancho Bernardo Study. Am J Epidemiol 145: 970 - 976

Gunnell D, Oliver SE, Peters TJ, Donovan JL, Persad R, Maynard M, Gillatt D, Pearce A, Hamdy FC, Neal DE, Holly JM (2003) Are diet-prostate cancer associations mediated by the IGF axis? A cross-sectional analysis of diet, IGF-I and IGFBP-3 in healthy middle-aged men. $\mathrm{Br}$ J Cancer 88: $1682-1686$

Holly JM, Hughes SC (1994) Measuring insulin-like growth factors: why, where and how? J Endocrinol 140: $165-169$

Holmes MD, Pollak MN, Hankinson SE (2002a) Lifestyle correlates of plasma insulin-like growth factor I and insulin-like growth factor binding protein 3 concentrations. Cancer Epidemiol Biomarkers Prev 11: $862-867$

Holmes MD, Pollak MN, Willett WC, Hankinson SE (2002b) Dietary correlates of plasma insulin-like growth factor I and insulin-like growth factor binding protein 3 concentrations. Cancer Epidemiol Biomarkers Prev 11: $852-861$

Jones JI, Clemmons DR (1995) Insulin-like growth factors and their binding proteins: biological actions. Endocr Rev 16: 3-34

Juul A (2003) Serum levels of insulin-like growth factor I and its binding proteins in health and disease. Growth Horm IGF Res 13: 113-170

Kaklamani VG, Linos A, Kaklamani E, Markaki I, Mantzoros C (1999) Age, sex, and smoking are predictors of circulating insulin-like growth factor 1 and insulin-like growth factor-binding protein 3. J Clin Oncol 17: $813-817$

Landin Wilhelmsen K, Wilhelmsen L, Lappas G, Rosen T, Lindstedt G, Lundberg PA, Bengtsson BA (1994) Serum insulin-like growth factor I in a random population sample of men and women: relation to age, sex smoking habits, coffee consumption and physical activity, blood pressure and concentrations of plasma lipids, fibrinogen, parathyroid hormone and osteocalcin. Clin Endocrinol Oxf 41: 351 - 357

Lee HY, Chun KH, Liu B, Wiehle SA, Cristiano RJ, Hong WK, Cohen P, Kurie JM (2002) Insulin-like growth factor binding protein-3 inhibits the growth of non-small cell lung cancer. Cancer Res 62: 3530-3537

Leung K-C, Johannsson G, Leong GM, Ho KKY (2004) Estrogen regulation of growth hormone action. Endocr Rev (in press)

Ma J, Giovannucci E, Pollak M, Chan JM, Gaziano JM, Willett W, Stampfer MJ (2001) Milk intake, circulating levels of insulin-like growth factor-I, and risk of colorectal cancer in men. J Natl Cancer Inst 93: 1330-1336

McCaffery K, Wardle J, Nadel M, Atkin W (2002) Socioeconomic variation in participation in colorectal cancer screening. J Med Screen 9: 104-108

McCaig C, Perks CM, Holly JM (2002) Intrinsic actions of IGFBP-3 and IGFBP-5 on Hs578T breast cancer epithelial cells: inhibition or accentuation of attachment and survival is dependent upon the presence of fibronectin. J Cell Sci 115: $4293-4303$

McTiernan A (2003) Intervention studies in exercise and cancer prevention. Med Sci Sports Exerc 35: $1841-1845$

Peto R, Darby S, Deo H, Silcocks P, Whitley E, Doll R (2000) Smoking, smoking cessation, and lung cancer in the UK since 1950: combination of national statistics with two case-control studies. BMJ 321: $323-329$

Platz EA, Pollak MN, Rimm EB, Majeed N, Tao Y, Willett WC, Giovannucci E (1999) Racial variation in insulin-like growth factor-1 and binding protein-3 concentrations in middle-aged men. Cancer Epidemiol Biomarkers Prev 8: $1107-1110$
Pollak M (2000) Insulin-like growth factor physiology and cancer risk. Eur J Cancer 36: $1224-1228$

Rajaram S, Baylink DJ, Mohan S (1997) Insulin-like growth factor-binding proteins in serum and other biological fluids: regulation and functions. Endocr Rev 18: $801-831$

Renehan AG (2004) IGFs and Cancer. www.christie.man.ac.uk/profinfo/ departments/surgery/default.htm

Renehan AG, Jones J, O'Dwyer ST, Shalet SM (2003) Determination of IGFI, IGF-II, IGFBP-2, and IGFBP-3 levels in serum and plasma: comparisons using the Bland-Altman method. Growth Horm IGF Res 13: $341-346$

Renehan AG, O'Dwyer ST, Shalet SM (2000a) RESPONSE: more about: prospective study of colorectal cancer risk in men and plasma levels of insulin-like growth factor (IGF)-I and IGF-binding protein-3. J Natl Cancer Inst 92: 1949-1950

Renehan AG, Painter JE, Atkin WS, Potten CS, Shalet SM, O' Dwyer ST (2001) High-risk colorectal adenomas and serum insulin-like growth factors. Br J Surg 88: $107-113$

Renehan AG, Painter JE, O'Halloran D, Atkin WS, Potten CS, O'Dwyer ST, Shalet SM (2000b) Circulating insulin-like growth factor II and colorectal adenomas. I Clin Endocrinol Metab 85: 3402 - 3408

Renehan AG, Zwahlen M, Minder C, O’Dwyer ST, Shalet SM, Egger M (2004) Insulin-like growth factor (IGF)-I, IGF binding protein-3, and cancer risk: systematic review and meta-regression analysis. Lancet 363: $1346-1353$

Sargeant LA, Khaw KT, Bingham S, Day NE, Luben RN, Oakes S, Welch A, Wareham NJ (2001) Cigarette smoking and glycaemia: the EPIC-Norfolk Study. European Prospective Investigation into Cancer. Int J Epidemiol 30: $547-554$

Teramukai S, Rohan T, Eguchi H, Oda T, Shinchi K, Kono S (2002) Anthropometric and behavioral correlates of insulin-like growth factor I and insulin-like growth factor binding protein 3 in middle-aged Japanese men. Am J Epidemiol 156: 344-348

Thissen JP, Ketelslegers JM, Underwood LE (1994) Nutritional regulation of the insulin-like growth factors. Endocr Rev 15: 80-101

Voskuil DW, de Mesquita HB, Kaaks R, van Noord PA, Rinaldi S, Riboli E, Grobbee DE, Peeters PH (2001) Determinants of circulating insulin-like growth factor (IGF)-I and IGF binding proteins $1-3$ in premenopausal women: physical activity and anthropometry (Netherlands). Cancer Causes Control 12: $951-958$

Wakai K, Ito Y, Suzuki K, Tamakoshi A, Seki N, Ando M, Ozasa K, Watanabe Y, Kondo T, Nishino Y, Ohno Y (2002) Serum insulin-like growth factors, insulin-like growth factor-binding protein-3, and risk of lung cancer death: a case-control study nested in the Japan Collaborative Cohort (JACC) Study. Jpn J Cancer Res 93: 1279-1286

$\mathrm{Yu} \mathrm{H}$, Rohan T (2000) Role of the insulin-like growth factor family in cancer development and progression. J Natl Cancer Inst 92: $1472-1489$

\section{Appendix A1}

A comparison of the baseline characteristics of the study participants with UK population is given in Table Al.

\section{Appendix B1}

A comparison of the baseline characteristics of study participants with EPIC-Norfolk study is given in Table B1. 
Table AI

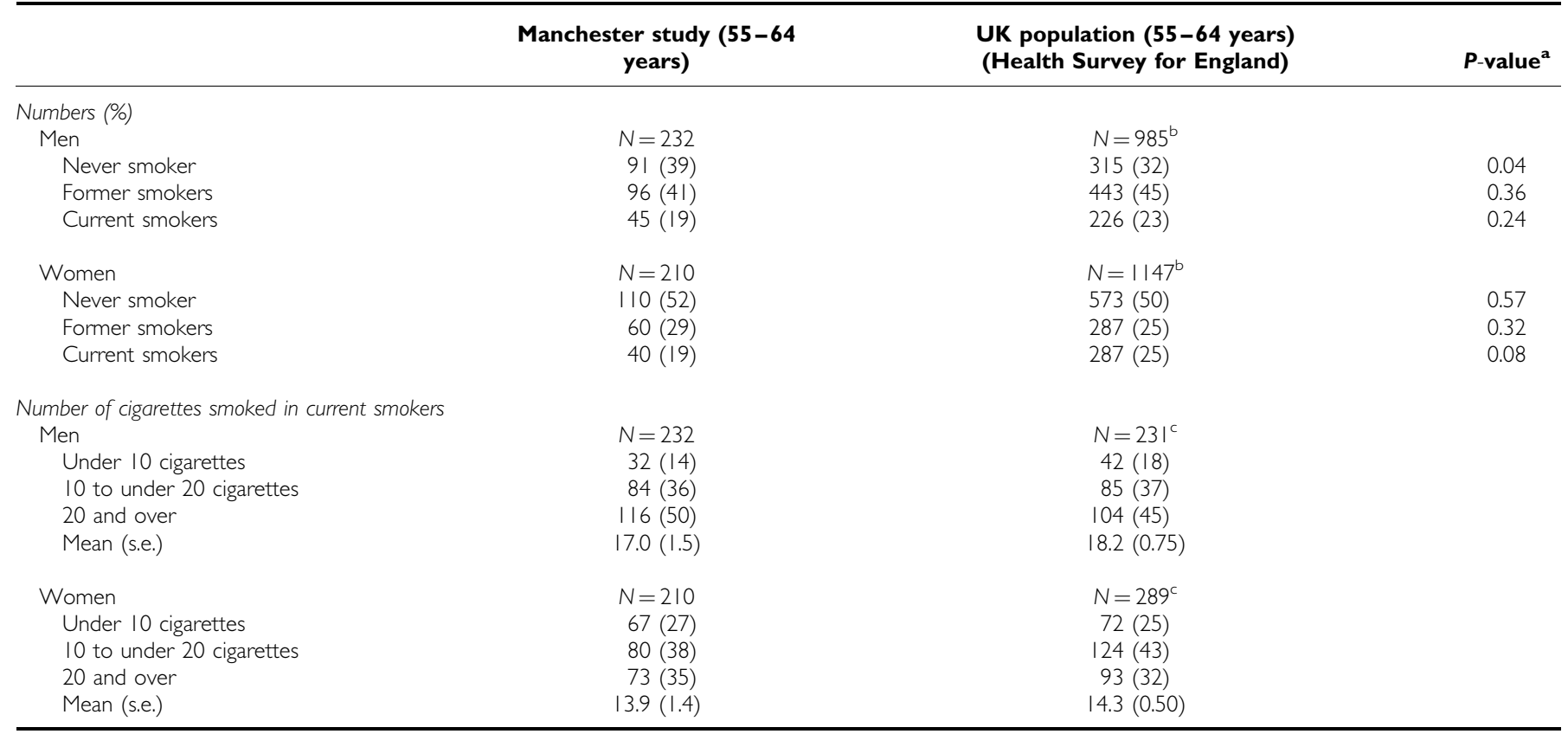

Values in parentheses are percentages unless otherwise stated. s.e. $=$ standard error. ${ }^{a} \chi^{2}$ test. ${ }^{b}$ Data from Health Survey of England, 1998 Cardiovascular Disease, Table 3.13. 'Data from Health Survey of England, 1998 Cardiovascular Disease, Table 3.22 (www.official-documents.co.uk/document/doh/survey98).

Table B I

\begin{tabular}{|c|c|c|c|c|c|c|c|c|}
\hline & \multicolumn{4}{|c|}{ Manchester study } & \multicolumn{4}{|c|}{ EPIC-Norfolk study } \\
\hline & $\begin{array}{l}\text { Never } \\
\text { smoker }\end{array}$ & $\begin{array}{l}\text { Former } \\
\text { smoker }\end{array}$ & $<15$ cig day $^{-1}$ & $\geqslant 15$ cig day $^{-1}$ & $\begin{array}{l}\text { Never } \\
\text { smoker }\end{array}$ & $\begin{array}{l}\text { Former } \\
\text { smoker }\end{array}$ & $<15$ cig day $^{-1}$ & $\geqslant 15$ cig day $^{-1}$ \\
\hline \multicolumn{9}{|l|}{ Men } \\
\hline No. of participants (\%) & $91(39)$ & $96(4 I)$ & $18(8)$ & $27(12)$ & $918(34)$ & | 463 (54) & $116(4)$ & $20(8)$ \\
\hline \multicolumn{9}{|l|}{ Mean (s.d.) } \\
\hline Pack-years smoking ${ }^{a}$ & - & $19(9-32)$ & $18(||-2 \mid)$ & $43(35-48)$ & - & $11(3-23)$ & $18(13-28)$ & $30.5(23-37)$ \\
\hline \multicolumn{9}{|l|}{ Numbers (\%) } \\
\hline Major illness ${ }^{b}$ & $23(25)$ & $42(44)$ & $4(22)$ & $8(30)$ & $250(27)$ & $513(35)$ & $34(29)$ & $43(2 \mathrm{I})$ \\
\hline \multicolumn{9}{|l|}{ Women } \\
\hline No. of participants (\%) & I $10(52)$ & $60(29)$ & $19(9)$ & $21(10)$ & $1894(56)$ & I 127 (33) & $191(6)$ & $173(5)$ \\
\hline \multicolumn{9}{|l|}{ Mean (s.d.) } \\
\hline Current HRT use & $42(38)$ & $23(38)$ & $8(42)$ & $10(48)$ & $291(20)$ & $230(26)$ & $38(26)$ & $37(29)$ \\
\hline
\end{tabular}

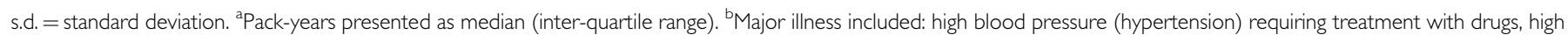
blood cholesterol (hyperlipidemia), angina, heart attack (myocardial infarction), stroke, other vascular disease (peripheral vascular disease), diabetes mellitus (excluding gestational diabetes) and cancer. 